\title{
Prevalence naturally infected gastrointestinal parasites and complete blood count condition on Wonosobo sheep at Wonosobo District, Central Java, Indonesia
}

\author{
ZEIN AHMAD BAIHAQI ${ }^{1, \vartheta}$, WISNU NURCAHYO ${ }^{2, \vee \vartheta}$, IRKHAM WIDIYONO $^{3, \vee \vee \vartheta}$ \\ ${ }^{1}$ Doctoral Program of Veterinary Science, Faculty of Veterinary Medicine, Universita Gadjah Mada. Jl. Fauna No. 2, Caturtunggal, Depok, Sleman \\ 55281, Yogyakarta, Indonesia. Tel.: +62-274-560861, `email: zein.ahmad.b@mail.ugm.ac.id \\ ${ }^{2}$ Department of Parasitology, Faculty of Veterinary Medicine, Universita Gadjah Mada. Jl. Fauna No. 2, Caturtunggal, Depok, Sleman 55281, \\ Yogyakarta, Indonesia. Tel.: +62-274-560861, •vemail: wisnu-nc@ugm.ac.id \\ ${ }^{3}$ Department of Internal Medicine, Faculty of Veterinary Medicine, Universita Gadjah Mada. Jl. Fauna No. 2, Caturtunggal, Depok, Sleman 55281, \\ Yogyakarta, Indonesia. Tel.: +62-274-560861, •v•email: irkhamwidiyono@ugm.ac.id
}

Manuscript received: 10 May 2020. Revision accepted: 14 May 2020

\begin{abstract}
Baihaqi ZA, Nurcahyo W, Widiyono I. 2020. Prevalence naturally infected gastrointestinal parasites and complete blood count condition on Wonosobo sheep at Wonosobo District, Central Java, Indonesia. Biodiversitas 21: 3057-3061. The aim of this study was to determine complete blood count of Wonosobo sheep infected with internal parasites on sheep farms in Wonosobo District, Central Java, Indonesia. Fecal and blood samples were taken from 130 female Wonosobo sheep. Fecal samples were individual and the numbers of worm eggs per gram of feces (eggs per gram, EPG) were counted. Complete blood count analyzed with a hematology analyzer machine and total protein were measured with a refractometer. The total average prevalence of gastrointestinal (GI) parasite infections in the Wonosobo sheep are $66.92 \%$. The prevalences of low EPG and high EPG GI parasite infections in female Wonosobo sheep were $19.23 \%$ and $47.69 \%$. The gastrointestinal worm species found infecting female Wonosobo sheep in this study were Haemonchus spp., Ostertagia spp., Trichostrongylus spp., Trichuris spp., Bunostomum spp., and Moniezia spp. The most prevalent GI parasites infections in Wonosobo sheep were caused by Haemonchus spp., and the last prevalent ones were caused by Trichuris spp. Mean Corpuscular Volume (MCV), Mean Corpuscular $\mathrm{Hb}(\mathrm{MCH})$, Mean Corpuscular Hb Concentration (MCHC), White Blood Cell (WBC), neutrophil, eosinophil, and lymphocyte counts in female Wonosobo sheep with naturally occurring gastrointestinal worms that had EPG $>600$ were significantly higher ( $p<0.001$ ) than those in sheep that had EPG <600. Hb, Hematocrit (HCT), Red Blood Cell (RBC), and Total Protein (TP) were significantly lower ( $<<$ $0.001)$ in sheep with EPG values $>600$ than in sheep with EPG $<600$. Monocyte and basophil values were not significantly different ( $p>$ 0.05 ) between infected sheep with EPG $<600$ and those with EPG $>600$. This study shows that gastrointestinal worm infections naturally affect the hematology and blood chemistry of female Wonosobo sheep in Wonosobo district, Central Java, Indonesia.
\end{abstract}

Keywords: Gastrointestinal, hematology, parasites, prevalence, Wonosobo sheep

\section{INTRODUCTION}

Mount Sumbing is the third-highest mountain on Java Island, Indonesia (3371 masl). The most abundant livestock commodity on Mount Sumbing is Wonosobo sheep. Wonosobo sheep are a new breed developed in Wonosobo District, Central Java Province, Indonesia, by crossbreeding local sheep with Texel sheep (Hakim et al 2019). More specifically, the Wonosobo sheep is the result of a cross between Texel sheep with thin-tailed or fat-tailed sheep in 1957, and has since been bred in the area of Wonosobo District, Central Java Province (The Decree of the Minister of Agriculture 2011).

GI nematode infections are one of the major health problems that hamper livestock production worldwide (Kumar et al. 2015). The parasites that often infect small ruminants are Haemonchus spp., Cooperia spp., Ostertagia spp., Bunostomum spp., Trichostrongylus spp., and Oesophagostomum spp. (Flores-Pereza et al. 2019). These infections may lead to diseases, leading to death or decreased production of milk, meat, and wool in these animals (Hakim et al. 2019). GI nematode infection is a major problem in small ruminant husbandry worldwide due to the impact of infection on the productivity and cost of the livestock industry (Nehra et al. 2019). Parasitic diseases in an area are influenced by topographical and geographical factors, in addition to the temperature and humidity conditions in an area is also very influential on the incidence of gastrointestinal nematode infections in ruminant animals (Bhattachryya et al. 2005)

Ruminant livestock productivity in Indonesia is hampered by widespread gastrointestinal nematode infections. Small ruminant animals are reported to be more susceptible to intestinal worms than other animals are (Mulyadi et al. 2018). The gastrointestinal worm most often found in sheep is Haemonchus contortus (Kumar et al. 2015), a nematode parasite of the ruminant abomasum; it has a cosmopolitan distribution and is a health problem for livestock around the world (Flores-Pereza et al. 2019). Haemonchosis leads to large economic losses because affected the livestock permanently lose body weight due to the infection (Nehra et al. 2019).

Livestock health status cannot be determined without considering hematologic parameters (Badawi et al. 2014). 
Blood parameter data can quantify the health status of sheep with Haemonchus contortus infections (Bell et al. 2019). The changes in hematological was observed in infected and non-infected livestock of gastrointestinal nematodes, this result can be applied as an alternative means of diagnosis and understanding disease prognosis of animal disease and status (Ngetich et al. 2019). Changes in the red blood cell indicated development of hemorrhagic anemia and changes in the white blood count could be attributed to the intensity of infection and the animal's response to pathogenesis of $H$. contortus (Sesztakova et al. 2019). Animals were affected by gastrointestinal parasites exhibited different clinical signs, a significant change in hematological and biochemical values between the infected and control animals (Osman et al. 2014). Hematological indices may pro-vide assessments of direct and indirect effects of parasite infection (Budischak et al. 2012). Hematological studies of sheep with diarrhea caused by gastrointestinal parasitic infections have shown significant decreases in $\mathrm{Hb}, \mathrm{PCV}$, and eosinophil count compared to control animals (Nehra et al. 2019). This study was conducted to evaluate the health status of female Wonosobo sheep with gastrointestinal worm infections by analyzing blood hematological parameters.

\section{MATERIALS AND METHODS}

\section{Ethical approval}

This research was approved by the Institutional Ethical Committee, Faculty of Veterinary Medicine, Gadjah Mada University, Yogyakarta, Indonesia. Nomor: 0013/ ECFKH/Int./2019.

\section{Study area}

Fecal and blood samples were collected from Wonosobo sheep on the slopes of Mount Sumbing (Klowoh Village), Wonosobo District, Central Java, Indonesia. This study used 130 female Wonosobo sheep aged of 1.5-2 years. The Wonosobo sheep are raised with forest grass feed. There are 2 to 3 sheep per cage. The number of cages inspected was 60 cages, the majority of cages located behind community houses. The position of the cage is not close and the management used was intensive management. This region (Klowoh Village) has a daily average temperature range of 19 to $25^{\circ} \mathrm{C}$, average humidity of $80 \%$, and an altitude of approximately $1300 \mathrm{~m}$ asl.

\section{Data analysis collection and sample analysis}

Sampling was conducted in September 2019 to Oktober 2019 at Klowoh village, Wonosobo district, Central Java Province. Fecal samples were taken from each sheep's rectum, and blood was collected using a $5 \mathrm{ml}$ syringe in the jugular vein; the blood was quickly transferred to a $3 \mathrm{ml}$ EDTA tube. Parasitological examination was carried out at BBVet (Indonesian Veterinary Center) in Wates, Special Region of Yogyakarta. The number of eggs per gram (EPG) was calculated according to the nematode egg counts in a modified McMaster technique with fecal flotation solution using a sugar solution (Gupta et al. 2012). EPG classification followed (Vasileiou et al. 2019), with high EPG defined as EPG $\geq 600$ and low EPG defined as EPG <600. Blood samples were analyzed with Sysmex KX-21 hematology analyzer at the Integrated Research Laboratory (LPPT) of Gadjah Mada University. Hematological parameters hemoglobin $(\mathrm{Hb})$, leukocyte count, differential leukocyte count, red blood cell (RBC) count, hematocrit (HCT), mean corpuscular volume (MCV), mean corpuscular $\mathrm{Hb}(\mathrm{MCH})$, and mean corpuscular $\mathrm{Hb}$ concentration (MCHC) were estimated following standard methods (Benjamin et al. 2008). Total protein (TP) concentration was measured using a refractometer (Miglio et al. 2015).

\section{Statistical analysis}

The GI worm prevalence results were analyzed by descriptive statistics and the values of the hematological parameters and plasma proteins were analyzed using SPSS 21.0. Data that were normally distributed were analyzed using the unpaired two-sided Student's t-test, while those that failed normality were tested using the Mann-Whitney $\mathrm{U}$ test with significance set at $\mathrm{p}<0.05$.

\section{RESULTS AND DISCUSSION}

\section{Results}

The prevalence of GI parasites in female Wonosobo sheep at Wonosobo district in Table 1. Table 1 shows that the total average prevalence of GI parasite infections in the Wonosobo sheep is $66.92 \%$ in Klowoh Village from 130 female Wonosobo sheep.

The Correlation between sheep genetics and GI parasites in female Wonosobo sheep at Wonosobo district in Table 2. Table 2 shows the six types of parasites found in female Wonosobo sheep. The gastrointestinal worm species found infecting female Wonosobo sheep in this study were Haemonchus spp., Ostertagia spp., Trichostrongylus spp., Trichuris spp., Bunostomum spp., and Moniezia spp. The most prevalent GI parasites infections in Wonosobo sheep were caused by Haemonchus spp., and the last prevalent ones were caused by Trichuris spp.

The prevalence of clinical and sub-clinical GI parasites infestation in female Wonosobo sheep at Wonosobo district (Table 3). Table 3 shows that the average prevalence of GI parasite infections in the Wonosobo sheep is $66.92 \%$ in female Wonosobo sheep in Klowoh Village. The prevalences of low EPG and high EPG GI parasite infections in female Wonosobo sheep were $19.23 \%$ and $47.69 \%$, respectively.

The hematology and blood chemistry of female Wonosobo sheep with EPG $<600$ and EPG $>600$ are shown in (Table 4). Table 4 shows that the values of $\mathrm{Hb}$, HCT, $\mathrm{RBC}$, and TP in worm-infected sheep with high EPG were significantly lower than those in worm-infected sheep with low EPG $(\mathrm{p}<0.05)$. Meanwhile, RBC index values $(\mathrm{MCV}$, $\mathrm{MCH}$, and MCHC), leukocytes, neutrophils, eosinophils, and lymphocytes in worm-infected sheep with high EPG 
counts were significantly higher than those in low-EPG sheep $(\mathrm{p}<0.05)$. Monocytes and basophils did not show significant differences between the two levels of infection $(\mathrm{p}>0.05)$.

Table 1. Prevalence of GI parasites in sheep

\begin{tabular}{cccc}
\hline \multirow{2}{*}{ Type of sheep } & \multirow{2}{*}{} & \multicolumn{2}{c}{ Female sheep } \\
\cline { 3 - 4 } & & Positive & Prevalence (\%) \\
\hline Wonosobo sheep & 130 & 87 & 66.92 \\
\hline
\end{tabular}

Table 2. Correlation between sheep genetics and GI parasites

\begin{tabular}{lcc}
\hline \multicolumn{1}{c}{ GI Parasites } & $\begin{array}{c}\text { Wonosobo sheep } \\
(\mathbf{n = 1 3 0 )}\end{array}$ & $\begin{array}{c}\text { Prevalence } \\
(\mathbf{\%})\end{array}$ \\
\cline { 2 - 3 } & Positive & 52.30 \\
\hline Haemonchus spp. & 68 & 46.15 \\
Ostertagia spp. & 60 & 41.53 \\
Trichostrongylus spp. & 54 & 11.53 \\
Trichuris spp. & 15 & 16.92 \\
Bunostomum spp. & 22 & 27.69 \\
Monezia spp. & 36 & \\
\hline
\end{tabular}

Table 3. Prevalence of clinical and sub-clinical GI parasites infestation in Wonosobo sheep in Klowoh Village, Wonosobo District, Central Java, Indonesia

\begin{tabular}{|c|c|c|c|c|}
\hline \multirow{2}{*}{ Location } & \multirow{2}{*}{$\begin{array}{c}\text { Sheep } \\
\text { (n) }\end{array}$} & \multicolumn{2}{|c|}{ Prevalence } & \multirow{2}{*}{$\begin{array}{c}\text { Overall } \\
\text { prevalence }\end{array}$} \\
\hline & & high EPG & low EPG & \\
\hline $\begin{array}{l}\text { Klowoh } \\
(1250 \mathrm{~m} \text { asl) }\end{array}$ & 130 & $\begin{array}{c}47.69 \% \\
(62)\end{array}$ & $\begin{array}{c}19.23 \% \\
(25)\end{array}$ & $\begin{array}{c}66.92 \% \\
(87)\end{array}$ \\
\hline
\end{tabular}

Note: high EPG > 600, low EPG < 600

Table 4. Blood hematological and blood chemical parameters of infected sheep $(\mathrm{EPG}<600$ or low EPG and EPG > 600 or high EPG)

\begin{tabular}{llll}
\hline \multicolumn{1}{c}{ Parameter } & \multicolumn{1}{c}{ low EPG } & \multicolumn{1}{c}{ high EPG } & P-value \\
\hline $\mathrm{Hb}(\mathrm{g} / \mathrm{dL})$ & $8.71 \pm 2.91$ & $6.21 \pm 0.63$ & 0.001 \\
$\mathrm{HCT}(\%)$ & $26.80 \pm 2.80$ & $24.65 \pm 2.03$ & 0.001 \\
$\mathrm{MCV}(\mathrm{fL})$ & $32.00 \pm 5.43$ & $41.00 \pm 7.95$ & 0.001 \\
$\mathrm{MCH}(\mathrm{pg})$ & $9.90 \pm 2.02$ & $11.94 \pm 1.59$ & 0.001 \\
$\mathrm{MCHC}(\%)$ & $30.81 \pm 2.85$ & $35.65 \pm 3.70$ & 0.001 \\
$\mathrm{RBC}(\mathrm{x} \mathrm{106/ \mu L})$ & $8.60 \pm 2.09$ & $7.69 \pm 1.53$ & 0.001 \\
Leukocytes & $11.00 \pm 3.17$ & $17.10 \pm 1.97$ & 0.001 \\
(x 103/mm $\left.^{3}\right)$ & & & \\
Neutrophil $(\%)$ & $36.00 \pm 4.58$ & $42.00 \pm 3.68$ & 0.001 \\
Eosinophil (\%) & $19.00 \pm 3.21$ & $29.00 \pm 5.72$ & 0.001 \\
Basophil $(\%)$ & $0.00 \pm 0.00$ & $0.00 \pm 0.00$ & 1.000 \\
Lymphocyte $(\%)$ & $47.00 \pm 13.03$ & $59.00 \pm 12.00$ & 0.001 \\
Monocyte $(\%)$ & $3.00 \pm 0.65$ & $3.00 \pm 0.69$ & 0.919 \\
TP $(\mathrm{g} / \mathrm{dL})$ & $7.00 \pm 1.47$ & $5.00 \pm 1.14$ & 0.001 \\
\hline Note: high EPG $>600,10 w \mathrm{EPG}<600$ & &
\end{tabular}

Note: high EPG $>600$, low EPG $<600$

\section{Discussion}

The prevalence study of gastrointestinal worm infestation in 130 female Wonosobo sheep taken in Wonosobo District, Central Java Province, Indonesia showed that the total prevalence of GI worms which was classified as high as $66.92 \%$. This high prevalence is suspected because the Klowoh village is located on a high altitude so it has more frequent rainfall intensity so that temperature and humidity support the growth of gastrointestinal parasites. This is consistent with Singh et al. (2017) which states that the conditions of temperature and humidity of an area support the development of parasites, causing infective larvae to increase.

The most common type of worm found in this study is Haemonchus sp. This can happen because the female Haemonchus contortus type of worm has a high fertility rate. Singh et al. (2013) stated that the characteristics of female Haemonchus worms can lay fertile eggs that reach 10000 eggs every day. The level of fertility of the female Haemonchus was very instrumental in the high infestation of Haemonchus nematodes in Wonosobo District. In addition, the types of worms monitored in this study were Ostertagia spp., Trichostrongylus spp., Bunostomum spp., Moniezia spp. and Trichuris spp. Hutchinson (2009) states that parasites that often attack small rumors Haemonchus spp., Cooperia spp., Ostertagia spp., Bunostomum spp., Trichostrongylus spp. and Oesophagostomum spp.

Worm infections in small ruminants are a serious problem in developing countries, especially those related to the environment, nutrition, and poor sanitation. Gastrointestinal nematode infection is one of the major health problems in the world that inhibits livestock production (Regassa et al. 2006). Nwosu et al. (2007) worm infections cause losses such as morbidity, mortality, reduction in feed conversion ratio, poor meat quality and incur more costs for the control of these parasites. Perry (2002) added that gastrointestinal (GI) nematode infection is a major problem in small ruminant production systems worldwide because of its impact on production and costs for control by livestock producers. The problem of nematode parasitism often occurs in developing countries due to unbalanced nutritional resources, resulting in impaired natural immunity so that it is easily infected with parasites, low productivity and high mortality.

The blood $\mathrm{Hb}, \mathrm{HCT}$, and RBC in Wonosobo sheep with high EPG $(>600)$ were significantly $(\mathrm{p}<0.05)$ lower than those in sheep with low EPG $(<600)$ and we noted a tendency for these values to decrease further with higher EPG values. Significant decreases in HCT and $\mathrm{Hb}$ values were also reported in worm-infected goats (Sanyal et al. 2014). Worm infestation in Wonosobo sheep caused decreases in $\mathrm{Hb}, \mathrm{HCT}$, and $\mathrm{RBC}$ to below normal reference values, so the sheep can be categorized as anemic. Normal sheep $\mathrm{Hb}$ values are in the range of 9.0-15.0 g/dl, HCT in the range of $27 \%-45 \%$, and $\mathrm{RBC}$ in the range of 9.0-15.0 $\mathrm{x} 106 / \mu \mathrm{L}$ (Weiss et al. 2010). Our findings are in line with the results of previous studies. Etim et al. (2014) found that $\mathrm{RBC}, \mathrm{PCV}$, and $\mathrm{Hb}$ levels in animals infected with gastrointestinal worms were significantly lower than in healthy animals (Etim et al. 2014). Kumar et al. (2015) 
showed that sheep with diarrhea due to gastrointestinal worm infections had decreased $\mathrm{Hb}, \mathrm{PCV}$, and $\mathrm{RBC}$ values. Furthermore, Haemonchus contortus infections in ruminant abomasa cause changes in hematology and blood biochemistry, and inflammation of the mucosa occurs after the Haemonchus parasite attaches to the abomasal mucosa, and may, therefore, lead to anemia and death (Schafera et al. 2019).

In animals infected with Nematoda gastrointestinal, $\mathrm{MCV}, \mathrm{MCH}$, and $\mathrm{MCHC}$ values were significantly higher in high EPG sheep than in low EPG sheep ( $p<0.05)$. EbeNwiyi confirms that higher $\mathrm{MCV}, \mathrm{MCH}$, and $\mathrm{MCHC}$ values can be correlated with anemia caused by a parasitic infection (Egbe-nwiyi et al. 2000). In normal sheep, MCV values are $28-40 \mathrm{fL}, \mathrm{MCH}$ is $8.0-12.0 \mathrm{pg}$, and $\mathrm{MCHC}$ is $31 \%-34 \%$ (Weiss et al. 2010).

Leukocyte counts in female Wonosobo sheep with high EPG were significantly higher than in those with low EPG $(\mathrm{p}<0.05)$. Normal sheep leukocytes counts are 4.0-8.0 thousand/mm3 (Weiss et al. 2010). Leukocyte counts in this study were above the normal range because of the infection with gastrointestinal worms. Bakker et al. (2004) found that sheep that were infected by gastrointestinal parasites showed significant increases in WBC, possibly due to the immune response to parasitic infections. Ganguly et al. (2016) found that in sheep, the number of leukocytes increased significantly due to parasitic infection. Leukocytes play an important role in the cellular defense of organisms against parasitic infections.

The eosinophil and lymphocyte values in female Wonosobo sheep with high EPG counts were significantly higher than those in low EPG sheep. Normal sheep eosinophil values are $0 \%-10 \%$, and normal lymphocytes are 40\%-55\% (Weiss et al. 2014). Eosinophils are effective in killing parasites, so the higher the infectious gastrointestinal parasite load, the higher the measured eosinophil count (Meeuse et al. 2000). The number of eosinophils produced by an animal's body can determine the animal's level of resistance to parasitic disease infections (Stear et al. 1994). In sheep, eosinophils play an important role in the development of resistance to several gastrointestinal parasites (Balic et al. 2006). Lymphocytes are parts of white blood cells that help prevent and fight parasitic infections in livestock (Douglas et al. 2010).

Serum TP concentrations in female Wonosobo sheep with high EPG were significantly lower compared to concentrations in sheep with low EPG. Normal sheep TP values are 6.2-7.7 g/dL (Rahman et al. 2018). In sheep infected with gastrointestinal worms in this study, there was a decrease in TP with an increase in infestation. The biochemical profile of sheep infected with gastrointestinal worms showed a significantly decreased TP value (Kumar et al. 2015). Trichostrongylus infection is associated with extensive damage to the duodenal mucosa and with general signs of enteritis, including bleeding, edema, and loss of plasma proteins into the intestinal lumen, and subsequent hypoalbuminemia and hypoproteinemia (Barker et al. 1982). Infection in high numbers causes protracted watery diarrhea and death. Trichostrongylus spp. disrupts the digestion process and absorption of nutrients and minerals.
This damage is caused by enteritis with atrophy of the mucosal microvillus and duodenal mucosal epithelial erosion, leukocyte infiltration, and high exudation of the intestinal lumen serum protein (Taylor et al. 2010).

Conclusion of this study is the total average prevalence of GI parasites infections in the female Wonosobo sheep is $66.92 \%$. The most prevalent GI parasites infections in Wonosobo sheep were caused by Haemonchus spp., and the last prevalent ones were caused by Trichuris spp. Natural infections of gastrointestinal worms have significant effects on the hematological and blood chemistry values of the blood of female Wonosobo sheep kept on the slopes of Mount Sumbing.

\section{ACKNOWLEDGEMENTS}

This study was supported by the Ministry of Research, Technology and Higher Education of the Republic of Indonesian through Pendidikan Magister Menuju Doktor untuk Sarjana Unggul (PMDSU) Program Grant Number 148/SP2H/PTNBH/DPRM/2018.

\section{REFERENCES}

Badawi NM, AL-Hadithy HAH. 2014. The hematological parameters in clinically healthy Iraqi Awassi sheep. World's Vet J 4 (1): 1-5.

Bakker N, Vervelde L, Kanobano K, Knox DP, Cornelissen AW, de Vries E, Yatsuda AP. 2004. Vaccination against the nematode $H$. contortus with a thiol binding fraction from the excretory, secretory products (ES). Vaccine 22 (5-6): 619-629.

Balic A, Cunningham CP, Meeusen ENT. 2006. Eosinophil interactions with Haemonchus contortus larvae in the ovine gastrointestinal tract. Parasite Immunol 28: 107-115.

Barker IK, Titchen DA. 1982. Gastric dysfunction in sheep infected with Trichostrongylus colubriformis, a nematode inhabiting the small intestine. Intl J Parasitol 12 (4): 345-356.

Bell A, McNally J, Smith DV, Rahman A, Hunt P, Kotze AC, Dominik S, Ingham A. 2019. Quantification of differences in resistance to gastrointestinal nematode infections in sheep using a multivariate blood parameter. Vet Parasitol 270: 31-39.

Benjamin MM. 2008. Outline of Veterinary Clinical Pathology 3rd ed. The Iowa State University, Press Ames, Iowa, USA.

Bhattachryya DK, Ahmed K. 2005. Prevalence of helminthic infection in cattle and buffaloes. Indian Vet J 82: 900-901.

Budischak SA, Jolles AE, Ezenwa VO. 2012. Direct and indirect costs of co-infection in the wild: Linking gastrointestinal parasite communities, host hematology, and immune function. Intl J Parasitol: Parasites Wildl 1: 2-12.

Douglas JW, Jane KW. 2010. Schalm's Veterinary Hematology Ed 7th. Blackwell Publishing Ltd, USA.

Egbe-nwiyi TN, Nwaosu, Salami HA. 2000. Haematological values of apparently healthy sheep and goats as influenced by age and sex. Afr J Biomed Res 3: 109-115.

Etim NN, Williams ME, Uduak AU, Offiong EEA. 2014. Haematological parameters and factors affecting their values. Agric Sci 2 (1): 37-47.

Flores-Péreza I, Hallal-Callerosa C, Cervantes-Pachecob BJ, AlbaHurtadoc F, Orihuelaa A, Castro-del-Campod N, Acevedo-Ramírezd P, Ortiz-Lópezd B, Jimenez-Leyvad D, Barajas-Cruzd R. 2019. Behavioural and productive response to experimental infection with stage 3 larvae of Haemonchus contortus in feedlot bull-calves. Exp Parasitol 197: 1-8

Ganguly A, Bisla RS, Chaudhri SS. 2016. Haematological and biochemical changes in ovine fasciolosis. Haryana Vet 55 (1): 27-30.

Gupta SK, Singla LD. 2012. Diagnostic trends in parasitic diseases of animals. In: Gupta RP, Garg SR, Nehra V, Lather D (eds). Veterinary Diagnostics: Current Trends. Satish Serial Publishing House, New Delhi. 
Hakim FR, Arifin M, Rianto E. 2019. Growth pattern and productivity of female Wonosobo sheep in Wonosobo District, Central Java Province, Indonesia. IOP Conf Series: Earth Environ Sci. DOI: 10.1088/1755-1315/247/1/012044

Hutchinson G. 2009. Nematode Parasites of Small Ruminants, Camelids and Cattle Diagnosis with Emphasis on Anthelmintic Efficacy and Resistance Testing. Elizabeth Mcarthur Agricultural Institute, New South Wales, Department of Primary Industries, Australia.

Kumar S, Jakhar KK, Singh S, Potliya S, Kumar K, Pal M. 2015. Clinicopathological studies of gastrointestinal tract disorders in sheep with parasitic infection. Vet World 8 (1): 29-32

Nehra AK, Gowane GR, Kuriyal A, Chaurasiya A, Kumar R, Bhinsara DB, Parthasarathi BC, Bhawana K, Khare RK, Prasad A, Chandra D, Sankar M. 2019. Immune response against subclinical haemonchosis in Himalayan hill goats. Vet Parasitol 267: 7-53.

Meeuse ENT, Balic A. 2000. Do eosinophils have a role in the killing of helminth parasites?. Parasitol Today 16 (3): 95-101.

Miglio A, Antognoni MT, Maresca C, Moncada C, Riondato F, Scoccia E Mangili V. 2015. Serum protein concentration and protein fractions in clinically healthy Lacaune and Sarda sheep using agarose gel electrophoresis. Vet Clin Pathol 44/4: 564-569.

Mulyadi T, Siswanto, Hartono M. 2018. Prevalence of gastrointestinal worms on Ettawa crossbreed goat in farmers group of Gedong Tataan district Pesawaran regency Lampung. Jurnal Riset dan Inovasi Peternakan 2 (2): 21-26. [Indonesia]

Ngetich EC, Ngeiywa M, Ng'wena GM, Chemwolo L. 2019. Haematological parameters by age and sex of asymptomatic indigenous cattle and sheep infected with gastrointestinal parasites in Kerio Valley, Kenya. Am J Biomed Res 7 (2): 44-50.

Nwosu CO, Madu PP, Richards WS. 2007. Prevalence and seasonal changes in the population of gastrointestinal nematodes of small ruminants in the semi-arid zone of North-Eastern Nigeria. Vet. Parasitol. 144 (1-2): 118-124.

Osman FA, Gaadee HI, Sayed GA. 2014. Clinico hematological and biochemical changes in camels affected with gastro-intestinal parasites. IJAVMS 8 (5): 154-161.

Perry B. 2002. Investing in Animal Health Research to Alleviate Poverty. International Livestock Research Institute, Kenya.

Rahman MK, Islam S, Ferdous J, Uddin MH, Hossain MB, Hassan MM, Islam A. 2018. Determination of hematological and serum biochemical reference values for indigenous sheep (Ovies aries) in Dhaka and Chittagong Districts of Bangladesh. Vet World 11 (8): 1089-1093.

Regassa F, Teshale S, Reta D, Yosef K. 2006. Epidemiology of gastrointestinal parasites of ruminants in Western Oromia, Ethiopia. Intl J Appl Res Vet Med 4 (1): 51-57.

Sanyal PK, Rawte D, Kerketta AE, Pal S, Baghel KR, Bisen S. 2014. Epidemiology and pathophysiology of caprine parasitic gastroenteritis in Chhattisgarh. Vet Parasitol 28 (1): 62-65.

Schafera AS, Baldissera MD, da Silva CB, de Oliveira JS, Francisco A, de Matos IM, Dornelles GL, Grando TH, Gressler LT, Stefanello S, Santi E, Minho AP, Rodrigues D, Souza CF, Leal MLR, Monteiro SG, Lopes STA, de Andrade CM. 2019. Copper oxide and closantel prevent alterations in hepatic energetic metabolism and reduce inflammation in Haemonchus contortus infection. Exp Parasitol. DOI: 10.1016/j.exppara.2019.107726

Sesztakova E, Konigova A,.Molnar L, Babjak M, Major P, Megyesi M, Vasilkova Z, Varady M. 2019. Changes in haematological parameters in wild ruminants experimentally infected with Haemonchus contortus. Helminthologia 56 (4): 303-309.

Singh V, Varshney P, Dash SK, Lal HP. 2013. Prevalence of gastrointestinal parasites in sheep and goats in and around Mathura. India Vet World 6 (5): 260-262.

Singh E, Kaur P, Singla LD, Bal MS. 2017. Prevalence of gastrointestinal parasitism in small ruminants in western zone of Punjab. India Vet World 10 (1): 61-66.

Stear MJ, Murray M. 1994. Genetic resistance to parasitic disease: Particularly of resistance in ruminants to gastrointestinal nematodes. Vet Parasitol 54: 161-176.

Taylor MA, Wall RL, Coop RL. 2010. Parasitologia Veterinária 3rd ed. Guanabara Koogan, Rio de Janeiro.

The Decree of the Minister of Agriculture. 2011. Cluster determination of Wonosobo sheep. No. 2915/Kpts/OT.140/6/2011.

Vasileiou NGC, Arsenopoulos K, Katsafadou AI, Angelou A, Mavrogianni VS, Fthenakis GC, Papadopoulos E. 2019. Interactions between parasitism and milk production - mastitis in sheep. Small Ruminant Res. DOI: 10.1016/j.smallrumres.2019.07.015.

Weiss DJ, Wardrop KJ. 2010. Schalms Veterinary Haematology 6th ed. Wiley- Blackwell, USA. 